\title{
Decolorization of synthetic dyes by laccase immobilized on epoxy-activated carriers
}

\author{
Adinarayana Kunamneni ${ }^{1}$, Iraj Ghazi ${ }^{1}$, Susana Camarero ${ }^{2}$, Antonio \\ Ballesteros $^{1}$, Francisco J. Plou ${ }^{1, *}$ and Miguel Alcalde ${ }^{1}$ \\ ${ }^{1}$ Departamento de Biocatálisis, Instituto de Catálisis y Petroleoquímica, CSIC, \\ Cantoblanco, 28049 Madrid, Spain. \\ ${ }^{2}$ Departamento de Microbiología Molecular, Centro de Investigaciones Biológicas, \\ CSIC, 28040 Madrid, Spain.
}

*Corresponding author. Tel.: +34 91 5854869; fax: +34 915854760

E-mail address: fplou@icp.csic.es 


\begin{abstract}
The Myceliophthora thermophila laccase was covalently immobilized on polymethacrylate-based polymers (Sepabeads EC-EP3 and Dilbeads NK) activated with epoxy groups. The enzyme immobilized on Sepabeads EC-EP3 exhibited notable activity $(203 \mathrm{U} / \mathrm{g})$ along with remarkably improved stability towards $\mathrm{pH}$, temperature and storage time, but no increased resistance to organic solvents. In addition, the immobilized laccase also showed good operational stability, maintaining $84 \%$ of its initial activity after 17 cycles of oxidation of ABTS. The immobilized biocatalyst was applied to the decolorization of six synthetic dyes. Immobilized laccase retained $41 \%$ activity in the decolorization of Methyl Green in a fixed-bed reactor after five cycles. The features of these biocatalysts are very attractive for their application on the decolorization of dyes in the textile industry in batch and continuous fixed-bed bioreactors. To our knowledge, this is the first report on immobilization of laccase on Sepabeads carriers and its efficient dyes decolorization.
\end{abstract}

Keywords: Covalent immobilization; Epoxy carriers; Acrylic polymers; Laccase; Decolorization; Synthetic dyes 


\section{INTRODUCTION}

Synthetic dyes are extensively used in several industries including textile, paper, printing, cosmetics and pharmaceuticals [1]. There are many structural varieties of dyes respecting the type of chromophore (part of the molecule responsible for its colour), such as azo, anthraquinone, acridine, arylmethane, cyanine, phthalocyanine, nitro, nitroso, quinone-imine, thiazole or xanthene dyes. On the basis of dyeing process, textile dyes are classified as reactive dyes, direct dyes, disperse dyes, acid dyes, basic dyes and vat dyes. It is estimated that $10-15 \%$ of the dyes are lost in the effluent during dyeing process [2,3]. Many synthetic dyes are difficult to decolorize due to their complex structure. Decolorization of textile dye effluent does not occur when treated aerobically by municipal sewage systems [4]. Brightly colored, watersoluble reactive and acid dyes are the most problematic, as they tend to pass through conventional treatment systems unaffected [4]. Color can be removed from effluent by chemical and physical methods including adsorption, coagulation-flocculation, ionexchange, oxidation and electrochemical methods $[5,6]$. The above ways for clean-up are expensive, which limit their application [7]. Dye decolorization is also achieved by routine anaerobic treatment of the effluents. However, reduction of azo dyes (up to $50 \%$ of the total amount of dyes used in the textile industry) by the bacterial reductases produce uncoloured highly toxic aromatic amines. Alternatively, enzymatic oxidation of the dye using fungal oxidorreductases such as laccases has received great attention in recent years due to the efficient decolorization of the effluent [8-12].

Laccases (EC 1.10.3.2) are blue multi-copper-containing enzymes that catalyze the oxidation of a variety of organic substances coupled to the reduction of molecular oxygen to water [13-15]. Because of their broad specificity for the reducing substrates, laccases from white-rot fungi are receiving increasing attention as potential industrial 
enzymes in various applications, such as pulp delignification, wood fiber modification, dye or stain bleaching, chemical or medicinal synthesis, and contaminated water or soil remediation [16]. Further, the presence of small molecular weight redox mediator enhances the range and the rates of compounds to be oxidized (including recalcitrant dyes) by the so-called laccase mediator system -LMS- [17]. Recently Camarero et al. [18] reported that some lignin-derived compounds served as eco-friendly laccase mediators that showed higher decolorization abilities against recalcitrant dyes than some synthetic mediators. Regardless of the nature of the mediator, several limitations prevent the use of free LMS for these applications. The stability and catalytic ability of free enzymes are dramatically decreased by highly polluted wastewaters; besides, mediator by-products can inactivate the laccase. The use of immobilized enzymes can overcome some of these limitations and provide stable catalysts with long life times. Taking into account that LMS works through the specific oxidation of the redox mediator, the immobilized laccase can be readily recovered for reuse. In particular, immobilization by covalent coupling retains very high enzyme activity and is effective in removing color and phenolic compounds over wide ranges of $\mathrm{pH}$ and temperature $[19,20]$.

The purpose of the present study was to develop an effective method for the immobilization of laccase to decolorize an array of synthetic dyes in the presence of mediators. The specific objectives of the study were to (i) immobilize laccase on epoxy-activated acrylic polymers; (ii) determine the optimum $\mathrm{pH}$ and temperature, $\mathrm{pH}$ and thermal stability, storage stability, stability in organic solvents and re-usability of the immobilized laccase as compared to that of soluble enzyme; and (iii) evaluate the performance of the immobilized laccase in decolorization of synthetic dyes. 


\section{MATERIALS AND METHODS}

\subsection{Materials}

Sepabeads EC-EP3 and Dilbeads NK were kindly donated by Resindion S.R.L (Mitsubishi Chemical Corporation, Milan, Italy) and DilComplex (Fermenta Biotech Ltd., India), respectively. Reactive Black 5 (RB-5), Acid Blue 25, Methyl Orange, Remazol Brilliant Blue B (RBBR), Methyl Green and Acid Green 27 were purchased from Sigma-Aldrich. N-hydroxybenzotriazole (HBT) and 2,2'-Azino-bis(3ethylbenzthiazoline-6-sulfonic acid) (ABTS) were obtained from Sigma-Aldrich. All other reagents were used of analytical grade.

A DeniLite II S sample was kindly provided by Novozymes A/S. This formulation is commonly used in the textile industry in the finishing process for indigo-stained cloths. The laccase (EC 1.10.3.2) is produced by submerged fermentation of a genetically modified Aspergillus microorganism [21] containing the laccase gene derived from Myceliophthora thermophila, using recombinant DNA techniques.

\subsection{Laccase immobilization}

DeniLite II S was dissolved in 0.1 M sodium acetate buffer ( $\mathrm{pH} 4.5$ ), centrifuged and filtered to a final protein concentration of $5 \mathrm{mg} / \mathrm{ml}$. The DeniLite II S working solution $(20 \mathrm{ml})$ was adjusted to $\mathrm{pH} 9.0$ with $1 \mathrm{M}$ sodium carbonate buffer, and mixed with Sepabeads EC-EP3 or Dilbeads NK (1 g). Approximately $100 \mathrm{mg}$ protein was added per gram of carrier. The suspension was incubated at room temperature with roller shaking for $24 \mathrm{~h}$. The immobilized biocatalyst was then filtered through glass filter, washed $(3 \mathrm{x}$

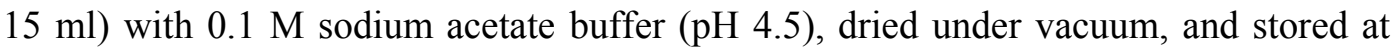
$4^{\circ} \mathrm{C}$. 


\subsection{Textural characterization of immobilized biocatalysts}

Mercury intrusion porosimetry analyses of the biocatalysts were performed using a Fisons Instruments Pascal 140/240 porosimeter; samples were dried at $100^{\circ} \mathrm{C}$ overnight, prior to measurement. The specific surface area $\left(\mathrm{S}_{\mathrm{BET}}\right)$ of the supports was determined from analysis of nitrogen adsorption isotherms at $-196^{\circ} \mathrm{C}$ using a Micromeritics ASAP 2010 device, the samples were previously degassed at $100^{\circ} \mathrm{C}$ for $12 \mathrm{~h}$ to a residual vacuum of $5 \times 10^{-3}$ torr, to remove any loosely held adsorbed species. Water content of the supports was assayed using a DL31 Karl-Fisher titrator (Mettler). Scanning electron microscopy (SEM) was performed using an XL3 microscope (Philips) on samples previously metallized with gold.

\subsection{Enzyme assay and protein estimation}

Standard laccase activity was determined by oxidation of ABTS at room temperature. The reaction solution was composed of $0.5 \mathrm{mM}$ ABTS in $0.1 \mathrm{M}$ sodium acetate buffer ( $\mathrm{pH} 4.5)$. A suitable amount of enzyme was added, and the oxidation of ABTS was followed by measuring the absorbance increase at $418 \mathrm{~nm}\left(\varepsilon_{\mathrm{ABTS}}{ }^{+}=36,000\right.$ $\left.\mathrm{M}^{-1} \mathrm{~cm}^{-1}\right)$. One unit of laccase activity corresponds to the oxidation of $1 \mu \mathrm{mol}$ ABTS/min under these conditions. For the determination of immobilized enzyme activity, $20 \mathrm{mg}$ of biocatalyst was incubated in $1 \mathrm{ml}$ reaction solution $(0.5 \mathrm{mM}$ ABTS $)$ under continuous stirring. Aliquots were withdrawn at fixed time intervals and the rest of the procedure as described above.

Protein estimation of free laccase was performed using the method of Bradford (BioRad protein assay). The quantity of protein bound to the support was calculated by subtracting the protein recovered in the combined washing of the support-enzyme complex from the protein used for immobilization. 


\subsection{Characterization of free and immobilized laccase}

\subsubsection{Optimum $\mathrm{pH}$ and $\mathrm{pH}$ stability}

Laccase activity (free or immobilized) was assayed using $0.5 \mathrm{mM}$ ABTS as substrate in $0.1 \mathrm{M}$ citrate-phosphate and Tris- $\mathrm{HCl}$ buffers $(\mathrm{pH} 2.0-9.0)$ at $30^{\circ} \mathrm{C}$. The effect of the $\mathrm{pH}$ on the enzyme stability was studied by incubating enzymes in $0.1 \mathrm{M}$ citratephosphate buffers ( $\mathrm{pH} 2.0-6.0$ ) for $24 \mathrm{~h}$ at $30^{\circ} \mathrm{C}$. Samples were transferred in standard reaction mixtures to determine the residual laccase activity with ABTS.

\subsubsection{Optimum temperature and thermostability}

The study was carried out at various temperatures $\left(30^{\circ}-80^{\circ} \mathrm{C}\right)$ and laccase activity was then assayed at the corresponding temperature in standard conditions. Thermal stability was determined by incubating free or immobilized laccases at the selected temperatures $\left(60^{\circ}\right.$ and $\left.70^{\circ} \mathrm{C}\right)$ for different times. After cooling, laccase activity was assayed at $30^{\circ} \mathrm{C}$ in standard conditions with ABTS.

\subsubsection{Stability in organic solvents}

The stability of the enzymes in organic solvents (methanol, ethanol, dimethylsulfoxide (DMSO) and acetonitrile) at different concentrations (10, 20, 30 and $50 \% \mathrm{v} / \mathrm{v}$ ) was measured by incubating free or immobilized enzyme in $1 \mathrm{ml}$ of the solutions at $30^{\circ} \mathrm{C}$ for $24 \mathrm{~h}$. Initial and final enzyme activity was measured at $30^{\circ} \mathrm{C}$.

\subsubsection{Storage stability}

For testing the storage stability of enzymes, free and immobilized laccases in $0.1 \mathrm{M}$ sodium acetate buffer $(\mathrm{pH} 4.5)$ were stored in a refrigerator at $4^{\circ} \mathrm{C}$ for several days. Then the remaining activity of the enzyme was measured at $30^{\circ} \mathrm{C}$ in standard conditions. 


\subsubsection{Reusability}

Several consecutive oxidative cycles were performed using $0.5 \mathrm{mM}$ ABTS in order to assess the operating stability of the immobilized laccase. At the end of each oxidation cycle, the immobilized laccase $(20 \mathrm{mg}$ or $5 \mathrm{U})$ was washed three times with sodium acetate buffer and the procedure repeated with a fresh aliquot of substrate, as described by Davis and Burns [19].

\subsection{Decolorization of synthetic dyes by immobilized laccase}

Assays of decolorization of $0.02 \%(\mathrm{w} / \mathrm{v})$ synthetic dyes (Fig. 1) were performed with $20 \mathrm{U}$ of immobilized laccase in $0.1 \mathrm{M}$ sodium acetate buffer $(\mathrm{pH} 4.5)$ with stirring (90 rpm) in $1 \mathrm{ml}$ Eppendorf tube at $30^{\circ} \mathrm{C}$. The reaction mixture was incubated for $24 \mathrm{~h}$ in the case of RB-5 and RBBR, and $6 \mathrm{~h}$ in the case of Acid Blue 25, Methyl Orange, Methyl Green, and Acid Green 27. The effect of redox mediator (1 mM HBT) on dyes decolorization was also investigated.

Decreases in the absorbance maxima characteristic of RB-5 (598 nm), RBBR (550 $\mathrm{nm})$, Acid Blue $25(600 \mathrm{~nm})$, Acid Green $27(650 \mathrm{~nm})$, Methyl Green (630 nm) and Methyl Orange $(470 \mathrm{~nm})$ were measured at different incubation times, and the percentage of dye decolorization was calculated from these data. Absorption spectra between 300 and $800 \mathrm{~nm}$ were recorded during dye decolorization with or without mediator by use of UV-visible spectrophotometer (UVIKON, Kontron). In parallel, control samples were maintained without enzyme under similar conditions.

\subsection{Fixed-bed bioreactor}

Methyl Green dye concentration was selected in order to obtain around 1.0 absorbance unit at its maximum visible wavelength. Twenty five $\mathrm{ml}$ of dye solution 
were circulated through a column $(5 \mathrm{~cm} \times 1 \mathrm{~cm})$ packed with immobilized laccase $(0.5$ g) at a flow rate of $5 \mathrm{ml} / \mathrm{min}$. Dye solution was continuously agitated with magnetic stirrer to assure proper oxygenation. After attaining the maximum decolorization of dye $(6 \mathrm{~h})$, the decolorized solution was replaced with fresh dye solution $(25 \mathrm{ml})$ and the process was repeated for several batches. Samples collected after each cycle and the absorbance of the dye was measured. 


\section{RESULTS AND DISCUSSION}

\subsection{Immobilization of laccase on Sepabeads EC-EP3 and Dilbeads NK}

When a protein is covalently linked to a support with a very high density of reactive groups, it was concluded that one must expect a multiple point attachment [22]. The immobilization of enzymes to epoxy-activated carriers is commonly carried out via multipoint covalent attachment at high ionic strength, because it has been postulated that, in a first step, a salt-induced association between the protein and the support surface takes place [23]. This interaction increases the effective concentration of nucleophilic groups on the enzyme close to the epoxide reactive sites. The epoxy (oxirane) groups may react with different nucleophiles of the protein as a function of $\mathrm{pH}$. At neutral or slightly alkaline $\mathrm{pH}$, with the thiol groups; at $\mathrm{pH}>9$, with the amino groups; at $\mathrm{pH}>11$, with phenolic groups of tyrosines; at slightly acidic $\mathrm{pH}$, with carboxyl groups [24]. Although the type of residues involved may affect the enzyme orientation on the solid support, it has been recently demonstrated by Wilchek and Miron [25] that there is little difference in biocatalyst performance when using random or oriented immobilization. In the present study, the laccase from M. thermophila was immobilized on two acrylic epoxy-activated polymers, Sepabeads EC-EP3 and Dilbeads NK. The main properties of these carriers are summarized in Table 1. As shown, Sepabeads EC-EP3 exhibits higher porosity and approximately double pore size than Dilbeads NK. Nevertheless, both carriers have a pore structure suitable to accommodate biomolecules. The particle size is not uniform for these supports, as shown in scanning electron microscopy (SEM) pictures of Fig. 2, in which the pore structure of both carriers is clearly different.

The activity towards ABTS of the M. thermophila working solution was 28 $\mathrm{U} / \mathrm{mg}$ protein. In order to bind the enzyme to the support using different functional 
groups, the immobilization was performed at $\mathrm{pH} 9.0$, adjusting the $\mathrm{pH}$ of soluble laccase with sodium carbonate. At $\mathrm{pH} 9.0$, the amino and thiol groups in the protein are able to bind to the support. The buffer concentration used was $1.0 \mathrm{M}$. The amount of total protein "offered" per gram of support was $100 \mathrm{mg}$.

As shown in Table 2, the amount of protein bound to Sepabeads EC-EP3 was almost 2-fold higher than the obtained with Dilbeads NK. The higher activity of the biocatalyst (203 U/g) was achieved with Sepabeads EC-EP3 than with Dilbeads NK (91 $\mathrm{U} / \mathrm{g}$ ). These results are promising-keeping in mind that the $M$. thermophila laccase expressed in $A$. oryzae is hyper-glycosylated by the eukaryotic host which may avoid higher number interactions between the enzyme surface and the activated carrier. Although laccase has been immobilized by different techniques, such as adsorption [26], entrapment [27] or covalent attachment [19], biocatalyst activity per mass unit is not commonly reported. However, Yinghui et al. [28] described a maximum activity of 1.2 U/g for laccase from Panus conchatus covalently attached to activated polyvinyl alcohol carrier.

\subsection{Characterization of immobilized laccase}

As the specific activity of laccase immobilized in Sepabeads EC3 was higher than in Dilbeads NK, we selected the former biocatalyst for further characterization studies.

\subsubsection{Optimum $\mathrm{pH}$ and $\mathrm{pH}$ stability}

The activity/pH profile of the immobilized laccase was not displaced as predicted from the neutral nature of the support (Fig. 3). Both the free and immobilized laccase exhibited maximal activity at $\mathrm{pH} 3.0$ and negligible activity above $\mathrm{pH}$ 7.0. The $\mathrm{pH}$ stability of free and immobilized laccase was determined over the restricted range 2.0- 
6.0. In general immobilized laccase exhibited higher stability than the free counterpart (Fig. 4), specially in the $\mathrm{pH}$ range 3.0-5.0.

\subsubsection{Optimum temperature and thermostability}

The activity/temperature profile of the soluble and immobilized enzyme showed the optimum of $60^{\circ} \mathrm{C}$ (Fig. 5A). In addition, immobilization resulted in a slight broadening of the curve at high temperatures, in agreement with other investigations [29-32]. At $75^{\circ}$ and $80^{\circ} \mathrm{C}$, immobilized laccase displayed a relative activity of 72 and $48 \%$, respectively, whereas the activity decay of the free enzyme was more significant at these temperatures (59 and 37\% relative activity, respectively).

The thermal stability is one of the most important features for the application of the biocatalyst. The immobilization of an enzyme to a carrier often limits its freedom to undergo drastic conformational changes, thus resulting in increased stability towards denaturation $[19,29,30,33]$. In the present study, laccase immobilization led to a significant stabilizing effect towards heat denaturation at 60 and $70^{\circ} \mathrm{C}$ (Fig. 5B). The stability at the above temperatures was increased respectively 15 and $10 \%$ in the immobilized enzyme, relative to the free one. The enhanced thermal stability of laccase arising from immobilization would be an advantage for its industrial application due to the high temperatures used in the industrial processes [32,34].

\subsubsection{Stability in organic solvents}

The effect of organic solvents on laccase activity has been reported [35-37]. Generally, laccases decrease their activity as concentrations of water-miscible solvents increase, and in most reported cases, immobilized laccase shows higher activity than the free enzyme at different organic solvents concentrations. Nevertheless, both free and immobilized laccases from Cerrena unicolor and Coriolodopsis gallica were not stable at concentration higher than 20\% [35-37]. These results are reasonably 
consistent with our results (cf. Table 3), in which different concentrations of organic solvents caused no significant differences for immobilized laccase and free preparations. The highest stability is observed for both soluble and immobilized laccase when using DMSO and ethanol as organic solvents.

\subsubsection{Storage stability}

Laccase immobilized on Sepabeads EC-EP3 maintained significant activity during storage at $4^{\circ} \mathrm{C}$ in $0.1 \mathrm{M}$ sodium acetate buffer $\mathrm{pH} 4.5$. During the first 2 months storage period there was a $2.5 \%$ drop in activity. Thereafter, the activity declined more slowly loosing an additional $1.3 \%$ in 2 months, equivalent to an approximate loss of $0.03 \%$ per day over the latter period and to a total loss of $3.8 \%$ in 4 months. Under the same storage conditions, the recovered activity of the soluble laccase amounted to 95 and 91\% after 2 and 4 months storage, respectively. Leonowicz and co-workers [30] reported an increase in storage stability of laccase from Trametes versicolor immobilized on glutaraldehyde-activated aminopropyl porous glass.

\subsubsection{Reusability}

The reusability of the laccase immobilized on Sepabeads EC-EP3 was also studied because of its importance for industry to reduce the processing costs. Fig. 6 clearly illustrates that immobilized laccase oxidized 17 batches of $0.5 \mathrm{mM}$ ABTS while retaining $84 \%$ initial activity. Successful reuse of various immobilized laccase systems has been reported by other investigators $[19,30,38]$.

\subsection{Decolorization of dyes by immobilized laccase}

We selected several dyes from the groups of diazo (RB-5), triarylmethane (Methyl Green), azo (Methyl Orange) and anthraquinone (Acid Green 27, Acid Blue 25

and RBBR) dyes to evaluate the enzymatic decolorization activity by the $M$. 
thermophila laccase immobilized on Sepabeads EC-EP3. The results showed a high decolorization capacity of laccase immobilized on Sepabeads (Figs. 7-8). In the case of RB-5 there was no decolorization with immobilized enzyme alone. The high redox potential of the dye $(1.4 \mathrm{~V})$, together with steric hindrances reducing the accessibility of the $-\mathrm{NH}_{2}$ and $-\mathrm{OH}$ groups, prevent the oxidation of the dye by laccase as observed previously with high redox potential laccases [18] or with Mn-mediated peroxidase activity [39]. However, in the presence of redox mediator (HBT) the immobilized enzyme exhibited efficient decolorization (60\%) after $24 \mathrm{~h}$. Murugesan et al. [3] found a similar result with RB-5 using laccase from Pleurotus sajor-caju. The probable reason is that the dyes containing $-\mathrm{NH} 2$ and $-\mathrm{OH}$ groups are most vulnerable by laccase attack; however, in RB-5, the steric hindrance may reduce the accessibility of these groups to laccases [18]. Recently, Camarero et al. [18] have reported that several lignin derived phenols of natural origin act as efficient redox mediators in the decolorization of RB-5.

Decolorization of the anthraquinone dye RBBR was not achieved by Denilite II as previously reported $[40,41]$ and in concordance with what occur with most laccases. On the contrary, Pycnoporus laccases posses high efficiency in decolorizing RBBR $[18,42]$. In the presence of HBT as redox mediator maximum decolorization of $31 \%$ was achieved after $24 \mathrm{~h}$. In contrast, the other anthraquinone dyes assayed (Acid Blue 25 and Acid Green 27) could be directly decolorized by immobilized enzyme. In the presence of HBT as redox mediator, there was no appreciable change in decolorization of these dyes. The immobilized enzyme also showed that there was no appreciable change in the decolorization of triarymethane dye Methyl Green (75\%) within 6 h with or without redox mediator. In the case of azo dye Methyl Orange, the immobilized enzyme showed $61 \%$ decolorization during $6 \mathrm{~h}$ incubation without HBT. However, the addition of $1 \mathrm{mM}$ 
HBT enhanced the decolorization nearly to 1.3 -fold and the maximum decolorization of $82 \%$ was observed within 6 h (Fig. 8). Efficient decolorization was confirmed by UVVisible spectroscopy showing a general decrease in dye adsorption in the 300 to $800 \mathrm{~nm}$ region (Fig. 7).

\subsection{Fixed-bed reactor}

The advantage of immobilized laccase lies not only in the increase of stability, but also in its reusability $[32,43]$. Experiments showed that the immobilized laccase on Sepabeads EC-EP3 could be reused 5 cycles for the decolorization of Methyl Green (Fig. 9). The immobilized laccase retained more than $41 \%$ of its initial activity after five batch uses. The activity loss in subsequent steps may be related with enzyme inactivation. The result revealed that immobilized laccase has potential application in dyestuff treatment [44]. 


\section{CONCLUSIONS}

Based on above results, the performance of the immobilized biocatalysts described in this work was satisfactory. Their high mechanical stability and absence of swelling in water converts them into very interesting alternatives for dye degradation in the textile industry, compared with other related carriers. In addition, immobilisation of laccase from DeniLite II S on epoxy-activated Sepabeads acrylic polymers is simple and easily scaleable. The use of the above biocatalysts for the batch and continuous decolorization of industrial dyes in a fixed-bed reactor is currently being studied. The improved stability and reusability of immobilized laccase could be a potential advantage in wastewater treatment. To our knowledge, this is the first report on immobilization of laccase on Sepabeads carriers and its efficient dyes decolorization.

\section{ACKNOWLEDGEMENTS}

We thank Drs. Moreno Daminati and Paolo Caimi (Resindion) and Vyasa Rajasekar (DilComplex) for providing us Sepabeads EC-EP3 and Dilbeads NK polymers, respectively. We are grateful to Ramiro Martínez (Novozymes A/S, Spain) for DeniLite II S samples. This material is based upon work founded by Spanish MEC (Projects VEM2004-08559 and CTQ2005-08925-C02-02/PPQ); European Union (Project NMP2CT-2006-026456) and CSIC (Project 200580M121). Spanish MEC is also thanked for the post-doctoral fellowship (SB2004-0011) of Dr. A. Kunamneni and for the Ramon y Cajal contracts of Drs. S. Camarero and M. Alcalde. 


\section{REFERENCES}

[1] Marmion DM. Handbook of US colorants. Foods, drugs, cosmetics and medical devices, 3rd ed., Wiley, New York, 1991.

[2] Zollinger H. Color chemistry-synthesis, properties and application for organic dyes and pigments, VCH Publications, New York, 1987. p. 92-102.

[3] Murugesan K, Dhamija A, Nam I-H, Kim Y-M, Chang Y-S. Decolourization of reactive black 5 by laccase: Optimization by response surface methodology. Dyes Pigments 2007;75:176-184.

[4] Willmott N, Guthrie J, Nelson G. The biotechnology approach to color removal from textile effluent. J Soc Dyes Colour 1998;114:38-41.

[5] Lin SH, Peng FC. Treatment of textile wastewater by electrochemical methods. Water Res 1994;28:277-82.

[6] Lin SH, Peng FC. Continuous treatment of textile wastewater by combined coagulation, electrochemical oxidation and activated sludge. Water Res 1996;30:587-92.

[7] Moreira MT, Mielgo I, Feijoo G, Lema JM. Evaluation of different fungal strains in the decolorization of synthetic dyes. Biotechnol Lett 2000;22:1499-1503.

[8] Abadulla E, Tzanov T, Costa S, Robra KH, Cavaco-Paulo A, Gubitz GM. Decolorization and detoxification of textile dyes with a laccase from Trametes hirsute. Appl Environ Microb 2000;66:3357-62.

[9] Claus H, Faber G, Konig H. Redox-mediated decolorization of synthetic dyes by fungal laccases. Appl Microbiol Biot 2002;59:672-78. 
[10] Zille A, Tzanov T, Gubitz GM, Cavaco-Paulo M. Immobilized laccase for decolorization of reactive black 5 dyeing effluent. Biotechnol Lett 2003;25:147377.

[11] Kandelbauer A, Erlacher A, Cavaco-Paulo A, Guebitz GM. Laccase-catalyzed decolorization of the synthetic azo-dye diamond black PV 200 and of some structurally related derivatives. Biocatal Biotransform 2004;22:331-39.

[12] Couto SR, Sanroman MA, Gubitz GM. Influence of redox mediators and metal ions on synthetic acid dye decolorization by crude laccase from Trametes hirsute. Chemosphere $2005 ; 58: 417-22$.

[13] Reinhammar BRM. Laccase. In Copper Proteins and Copper Enzymes, Enzymes, Chapter 1, Edited by R. Lontie. Boca Raton, FL: CRC Press, 1984. p. 1-35.

[14] Solomon EI, Sundaram UM, Machonkin TE. Multicopper oxidases and oxygenases. Chem Rev 1996;96:2563-2605.

[15] Alcalde M, Ferrer M, Plou FJ, Ballesteros A. Environmental biocatalysis: from remediation with enzymes to novel green processes. Trends Biotechnol 2006;24:281-87.

[16] Rodríguez Couto S, Toca Herrera JL. Lacasses in the textile industry. Biotechnol Mol Biol Rev 2006;1:115-20

[17] Reyes R, Pickard M, Vazquez-Duhalt, R. Hydroxybenzotriazole increase the range of textile dyes decolorized by immobilized laccase. Biotechnol Lett $1999 ; 21: 875-80$.

[18] Camarero S, Ibarra D, Martinez MA, Martinez AT. Lignin-derived compounds as efficient laccase mediators for decolorization of different types of recalcitrant dyes. Appl Environ Microb 2005;71:1775-84. 
[19] Davis S, Burns RG. Covalent immobilization of laccase on activated carbon for phenolic effluent treatment. Appl Microbiol Biot 1992;37:474-79.

[20] Rogalski J, Jozwik E, Hatakka A, Leonowicz A. Immobilization of laccase from Phlebia radiata on controlled porosity glass. J Mol Catal 1995;95:99-108.

[21] Sevendsen A. Laccase mutants. Patent No. WO 98/38286, 1998.

[22] Guisan JM, Melo FV, Ballesteros A. Determination of intrinsic properties of immobilized enzymes. 1. Appl Biochem Biotech 1981;6:25-36.

[23] Wheatley JB, Schmidt Jr DE. Salt-induced immobilization of affinity ligands onto epoxide-activated supports. J Chromatogr A 1999;849:1-12.

[24] Ghazi I, Gomez de Segura A, Fernandez-Arrojo L, Alcalde M, Yates M, RojasCervantes, Plou FJ, Ballesteros A. Immobilization of fructosyltransferase from Aspergillus aculeatus on epoxy-activated Sepabeads EC for the synthesis of fructo-oligosaccharides. J Mol Catal B-Enzym 2005;35:19-27.

[25] Wilchek M, Miron T. Oriented versus random protein immobilization. Biochem Biophys Methods 2003;55:67-70.

[26] Annia IR, Adriel JM, Claus F, Kai G. Improved activity and stability of an immobilized recombinant laccase in organic solvents. Biotechnol Lett 2000;22:229-33.

[27] Palmieri G, Giardina P, Desiderio B, Marzullo L, Giamberini M, Sannia G. A new enzyme immobilization procedure using copper alginate gel: application to a fungal phenol oxidase. Enzyme Microb Tech 1994;16:151-58. 
[28] Yingui D, Qiuling W, Shiyu F. Laccase stabilization by covalent binding immobilization on activated polyvinyl alcohol carrier. Lett Appl Microbiol 2002;35:451-56.

[29] Pye EK, Chance B. Investigations of the physical properties of immobilized enzymes. Method Enzymol 1976;44:357-72.

[30] Leonowicz A, Sarkar JM, Bollag, JM. Improvement in stability of an immobilized fungal laccase. Appl Microbiol Biot 1988;29:129-35.

[31] Berka RM, Schneider P, Golightly EJ, Brown SH, Madden M, Brown KM, Halkier T, Mondorf $\mathrm{K}, \mathrm{Xu} \mathrm{F}$. Characterization of the gene encoding an extracellular laccase of Myceliophthora thermophila and analysis of the recombinant enzyme expressed in Aspergillus oryzae. Appl Environ Microb 1997;63: 3151-57.

[32] D’Annibale A, Stazi SR, Vinciguerra V, Mattia ED, Sermanni GG. Characterization of immobilized laccase from Lentinula edodes and its use in olive-mill wastewater treatment. Process Biochem 1999;34:697-706.

[33] Klibanov AM. Enzyme stabilization by immobilization. Anal Biochem $1979 ; 93: 125$.

[34] Berrio J, Plou FJ, Ballesteros A, Martinez AT, Martinez MJ. Immobilization of Pycnoporous coccineus laccase on Eupergit C: Stability increase and treatment of oil mill wastewaters. Biocatal Biotransform 2007;25:000-000.

[35] Leutrek J, Gianfreda L, Wojtas-Wasilewska M, Cho NS, Rogalski J, Jaszek M, Malarczyk E, Staszczak M, Fink-Boots M, Leonowicz A. Activity of free and immobilized extracellular Cerrena unicolor laccase in water miscible organic solvents. Holzforschung 1998;52:589-95. 
[36] Rogalski J, Dawidowicz A, Jozwik E, Leonowicz A. Immobilization of laccase from Carrena unicolor on controlled porosity glass. J Mol Catal B-Enzym 1999;6:29-39.

[37] Pickard MA, Roman R, Tinoco R, Vazquez-Duhalt R. Polycyclic aromatic hydrocarbon metabolism by white rot fungi, and oxidation by Coriolodopsis gallica UAMH 8260 laccase. Appl Environ Microb 1999;65:3805-809.

[38] Shuttleworth KL, Bollag JM. Soluble and immobilized laccase as catalysts for the transformation of substituted phenols. Enzyme Microb Tech 1986;8:171-78.

[39] Heinfling A, Martinez MJ, Martinez AT, Bergbauer M, Szewzyk U. Transformation of industrial dyes by manganese peroxide from Bjerkandera adusta and Pleourotus eryngii in a manganese-independent reaction. Appl Environ Microb 1998;64:2788-93.

[40] Soares GMB, Costa-Ferreira M, de Amorim MTP. Decolorization of an anthraquinone-type dye using a laccase formulation. Bioresource Technol 2001;79:171-77.

[41] Soares GMB, de Amorim MTP, Costa-Ferreira M. Use of laccase together with redox mediators to decolourize Remazol Brilliant Blue R. J Biotechnol 2001;89:123-29.

[42] Lei L, Min Z, Bei-Bei Z, Shu-Yu Y, Xi-Jun B, Wei W, Yan W. Purification and characterization of laccase from Pycnoporus sanguineus and decolorization of an anthraquinone dye by the enzyme. Appl Microbiol Biot 2007;74:1232-39.

[43] Dodor DE, Hwang HM, Ekunwe SIN. Oxidation of anthracene and benzo [a] pyrene by immobilized laccase from Trametes versicolor. Enzyme Microb Tech 2004;35:210-17. 
[44] Lu L, Zhao M, Wang Y. Immobilization of laccase by alginate-chitosan microcapsules and its use in dye decolorization. World $\mathrm{J}$ Microb Biot 2007;23:159-66. 


\section{Table 1}

Main properties of the carriers employed in this study

\begin{tabular}{|c|c|c|}
\hline Properties & Sepabeads EC-EP3 & Dilbeads NK \\
\hline $\begin{array}{l}\text { Content of epoxide groups } \\
(\mu \mathrm{mol} / \mathrm{g})^{\text {a }}\end{array}$ & 106 & n.a \\
\hline Particle size $(\mu \mathrm{m})^{\mathrm{b}}$ & 77 & 103 \\
\hline $\mathrm{S}_{\mathrm{BET}}\left(\mathrm{m}^{2} / \mathrm{g}\right)^{\mathrm{c}}$ & 43 & 81 \\
\hline Pore volume $\left(\mathrm{cm}^{3} / \mathrm{g}\right)^{d}$ & 1.19 & 0.80 \\
\hline Average pore size (nm) & 130 & 67 \\
\hline Water content $(\%)^{\mathrm{e}}$ & 60 & 20 \\
\hline
\end{tabular}

a Provided by the supplier.

${ }^{\mathrm{b}}$ Determined by Hg porosimetry, considering a symmetric distribution of particle size.

${ }^{\mathrm{c}}$ Measured by $\mathrm{N}_{2}$ adsorption.

${ }^{d}$ By combination of $\mathrm{N}_{2}$ isotherms and $\mathrm{Hg}$ porosimetry.

${ }^{\mathrm{e}}$ Determined by Karl-Fisher titration.

n.a: not available. 
Table 2

Immobilization of laccase on different supports

\begin{tabular}{llll}
\hline Support & Added protein & Bound protein & Biocatalyst \\
& $(\mathbf{m g} / \mathbf{g}$ biocatalyst) & $\mathbf{( \% )}$ & activity (U/g) \\
\hline Sepabeads EC-EP3 & 100 & 32.6 & 203 \\
Dilbeads NK & 100 & 17.8 & 91 \\
\hline
\end{tabular}

Experimental conditions: $1 \mathrm{M}$ sodium carbonate buffer ( $\mathrm{pH} 9.0), 24 \mathrm{~h}$, room temperature and roller shaking,.

Table 3

Laccase stability in organic solvents at different concentrations

\begin{tabular}{|c|c|c|c|c|c|c|}
\hline \multirow[t]{2}{*}{ Solvent } & \multirow[t]{2}{*}{ Laccase } & \multicolumn{5}{|c|}{$\begin{array}{l}\text { Residual laccase activities (in \%) in various } \\
\text { concentrations of solvent }\end{array}$} \\
\hline & & $0 \%$ & $10 \%$ & $20 \%$ & $30 \%$ & $50 \%$ \\
\hline \multirow[t]{2}{*}{ Methanol } & Soluble & 100 & 93.6 & 88.9 & 63.5 & 16.1 \\
\hline & Immobilized & 100 & 97.3 & 86.1 & 65.7 & 18.3 \\
\hline \multirow[t]{2}{*}{ Ethanol } & Soluble & 100 & 96.2 & 93.0 & 83.5 & 51.6 \\
\hline & Immobilized & 100 & 98.6 & 98.1 & 85.4 & 57.9 \\
\hline \multirow[t]{2}{*}{ DMSO } & Soluble & 100 & 100 & 100 & 98.5 & 81.9 \\
\hline & Immobilized & 100 & 100 & 100 & 100 & 86.4 \\
\hline \multirow[t]{2}{*}{ Acetonitrile } & Soluble & 100 & 52.5 & 47.0 & 25.8 & 2.8 \\
\hline & Immobilized & 100 & 56.7 & 49.2 & 28.9 & 4.0 \\
\hline
\end{tabular}




\section{Figure legends.}

Fig. 1. Chemical structures of the different dyes: (A) RB-5 (Diazo type); (B) RBBR (Indigoid type); (C) Acid Blue 25 (Anthraquinone type); (D) Acid Green 27 (Anthraquinone type); (E) Methyl Orange (Azo type) and (F) Methyl Green (Triarylmethane type) and (G) redox mediator HBT.

Fig. 2. SEM pictures of Sepabeads EC-EP3 and Dilbeads NK at 25x (upper picture) and $8,000 \mathrm{x}$ (bottom picture).

Fig. 3. Effect of $\mathrm{pH}$ on free and immobilized laccase. $\mathrm{pH}$ in the range of 2.0-9.0 were tested with $0.5 \mathrm{mM}$ ABTS.

Fig. 4. $\mathrm{pH}$ stability profiles of (A) free and (B) immobilized laccase. $0.5 \mathrm{mM}$ ABTS was used as the substrate for enzyme assay.

Fig. 5. (A) Effect of the temperature on free and immobilized laccase. Various temperatures in the range of $30^{\circ}$ to $80^{\circ} \mathrm{C}$ were tested with $0.5 \mathrm{mM}$ ABTS as the substrate. (B). Thermostability profiles at $60^{\circ}$ and $70^{\circ} \mathrm{C}$ of free and immobilized laccase. $0.5 \mathrm{mM}$ ABTS was used as the substrate for enzyme assay.

Fig. 6. Operational stability of laccase immobilized on Sepabeads EC-EP3.

Fig. 7. Visible absorbance spectra of synthetic dyes (A) RB-5; (B) RBBR; (C) Acid Blue 25; (D) Acid Green 27; (E) Methyl Orange and (F) Methyl Green before and after 
treatment with immobilized laccase (in absence or presence of $1 \mathrm{mM}$ HBT). Incubation time: $24 \mathrm{~h}$ for $(\mathrm{A})$ and $(\mathrm{B}) ; 6 \mathrm{~h}$ for $(\mathrm{C}),(\mathrm{D}),(\mathrm{E})$ and $(\mathrm{F}) .(-)$ Non-treated ; $(\cdots \cdots \cdots)$ Treated with laccase; (-----) Treated with laccase and 1 mM HBT.

Fig. 8. Decolorization of synthetic dyes (A) RB-5; (B) RBBR; (C) Acid Blue 25; (D) Acid Green 27; (E) Methyl Orange and (F) Methyl Green with immobilized laccase in the absence (-) or presence (-----) of redox mediator HBT $(1 \mathrm{mM})$. Incubation time: $24 \mathrm{~h}$ for (A) and (B); $6 \mathrm{~h}$ for (C), (D), (E) and (F).

Fig. 9. Re-usability of laccase immobilized on Sepabeads EC-EP3 in fixed-bed reactor for the decolorization of Methyl Green. 


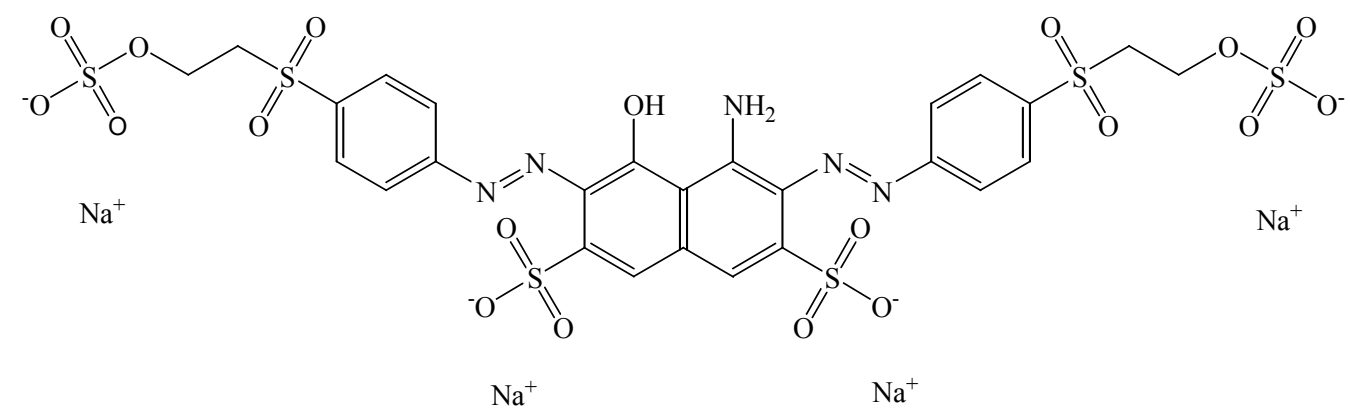

(A)<smiles>Nc1c(S(=O)(=O)O[Na])cc(Nc2cccc(S(=O)(=O)CCOS(=O)(=O)O)c2)c2c1C(=O)c1ccccc1C2=O</smiles>

(B)

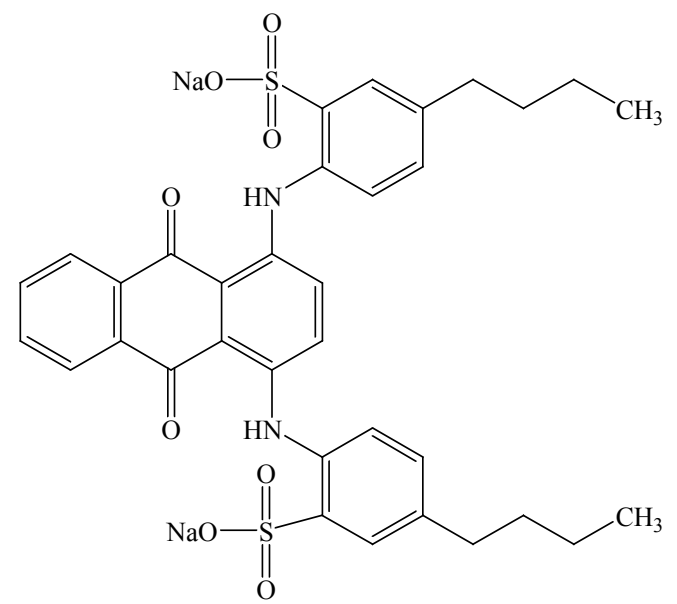

(D)<smiles>CC[N+](C)(C)c1ccc(C(=C2C=CC(=[N+](C)Cl)C=C2)c2ccc(N(C)C)cc2)cc1</smiles>

(F)

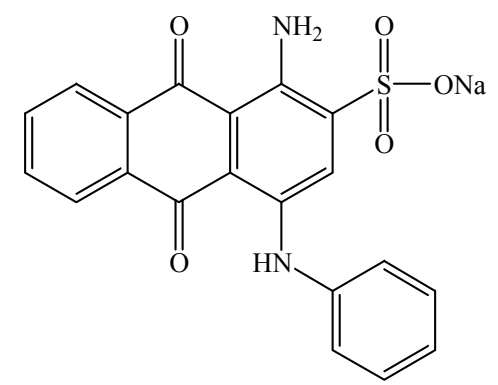

(C)

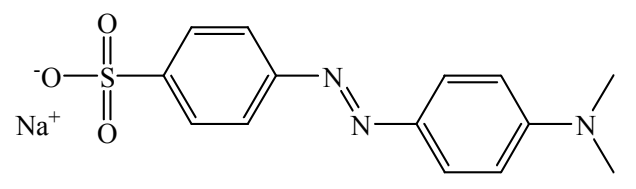

(E)

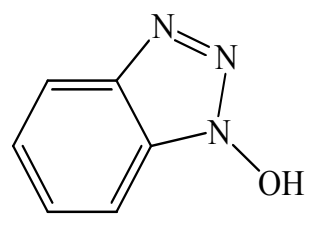

(G)

Fig. 1 

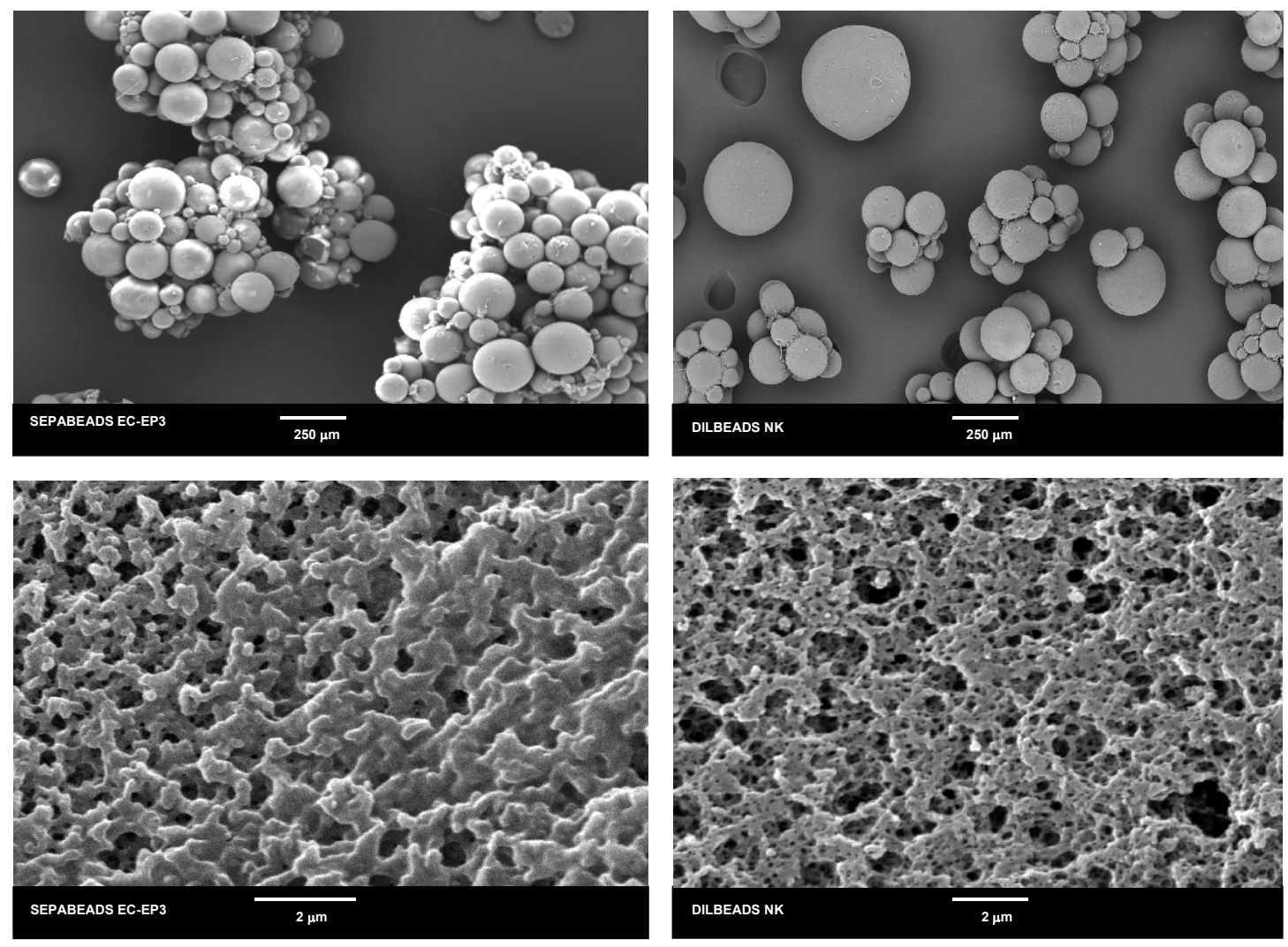

Fig. 2 


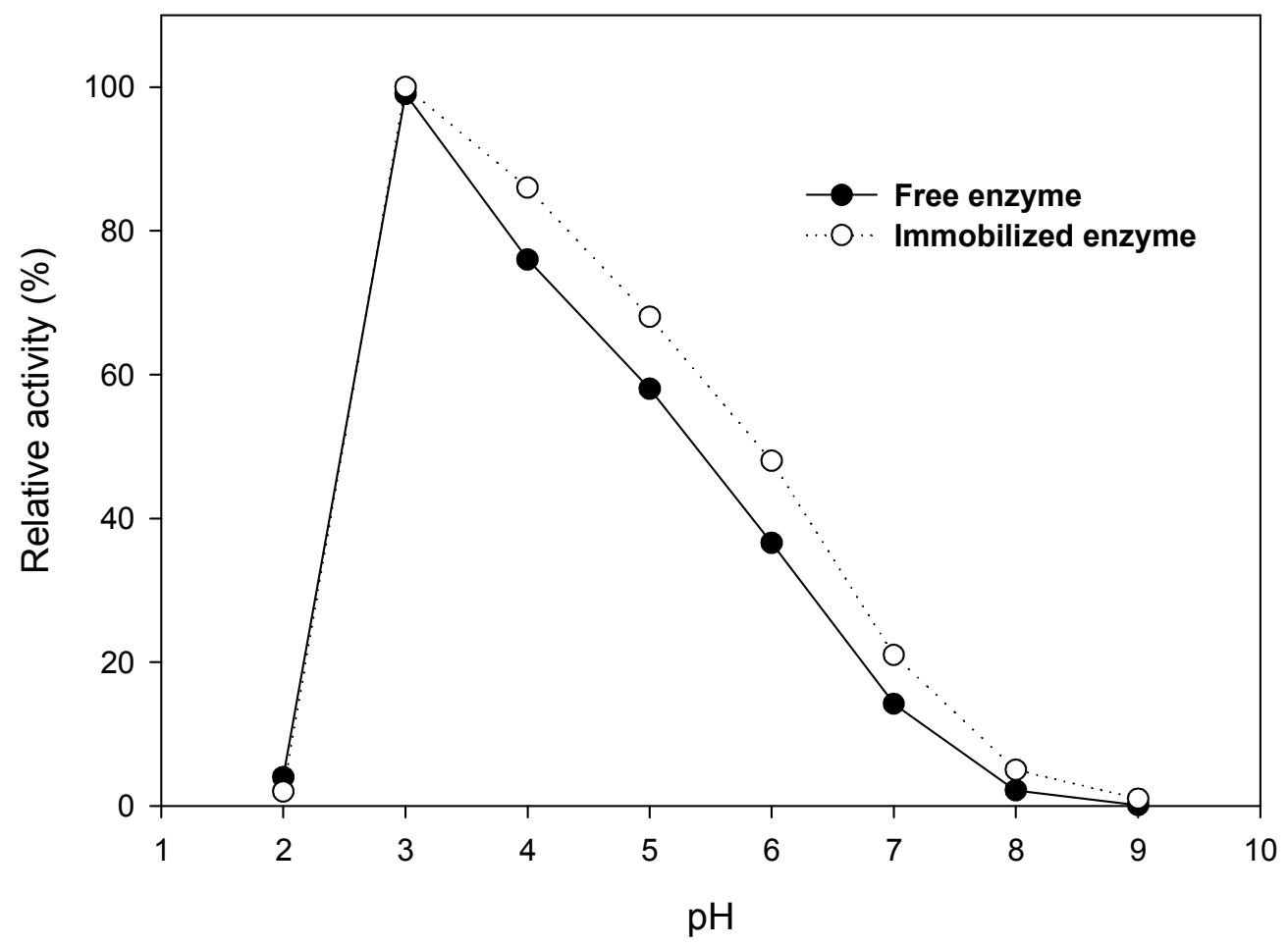

Fig. 3 

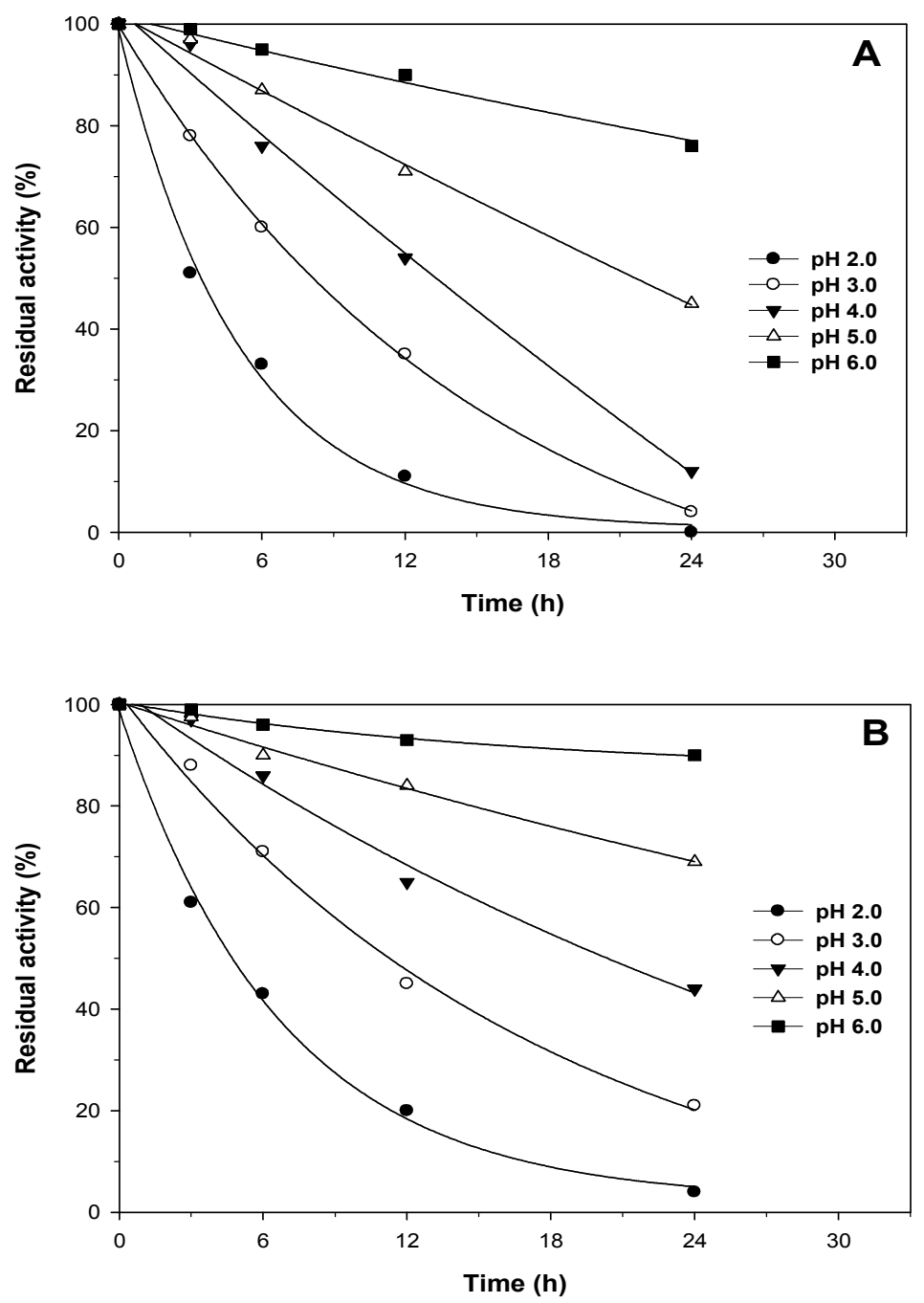

Fig. 4 

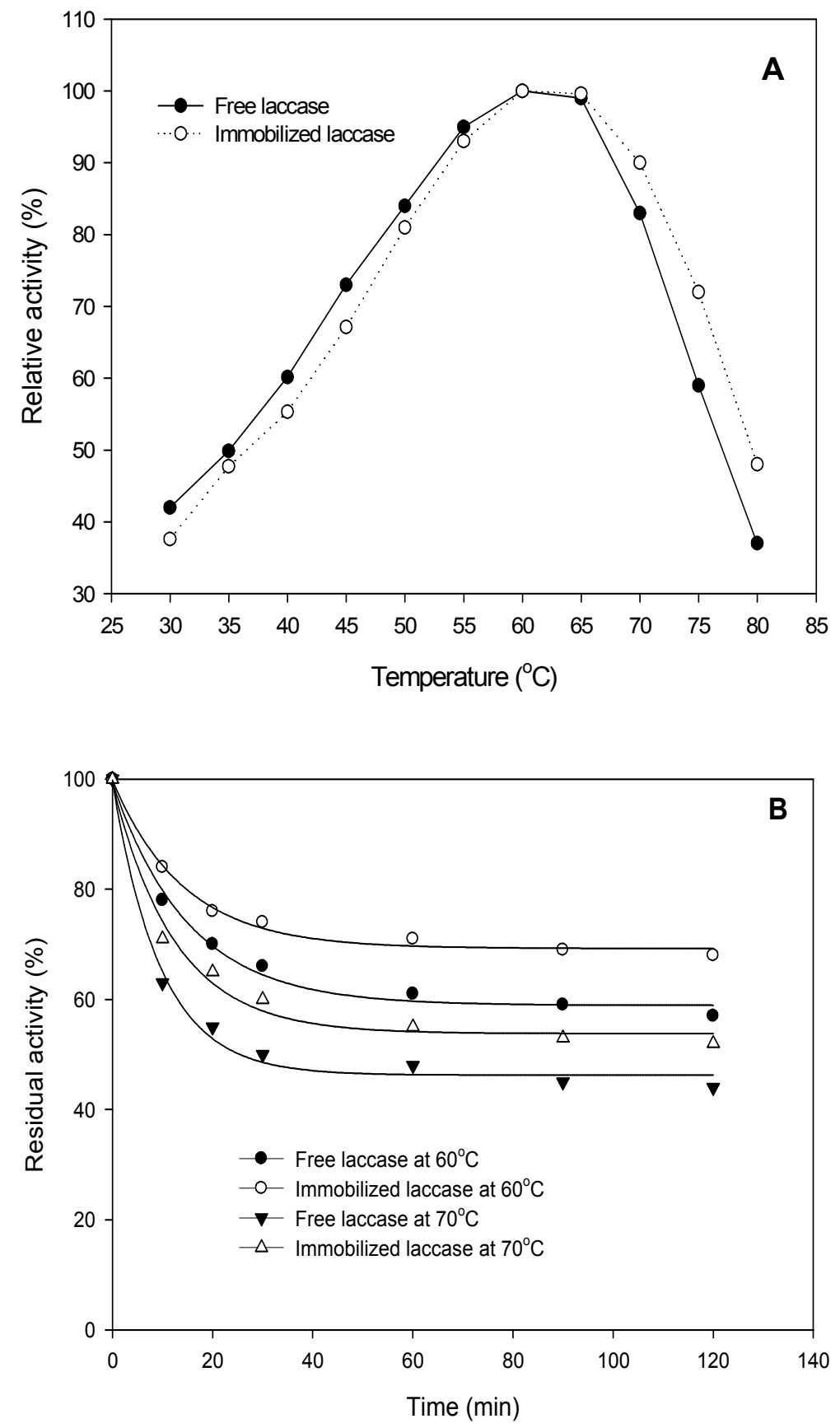

Fig. 5 


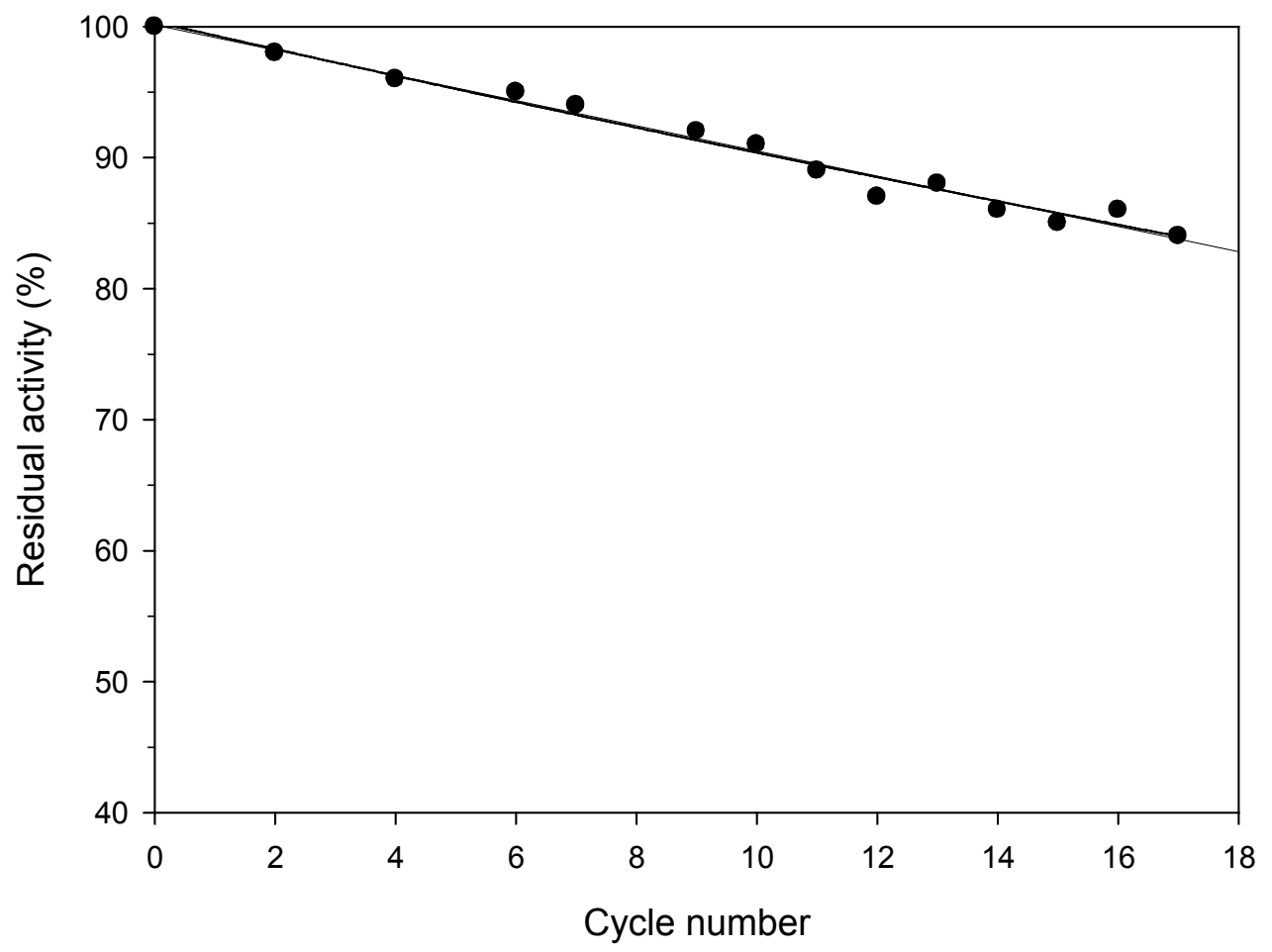

Fig. 6 

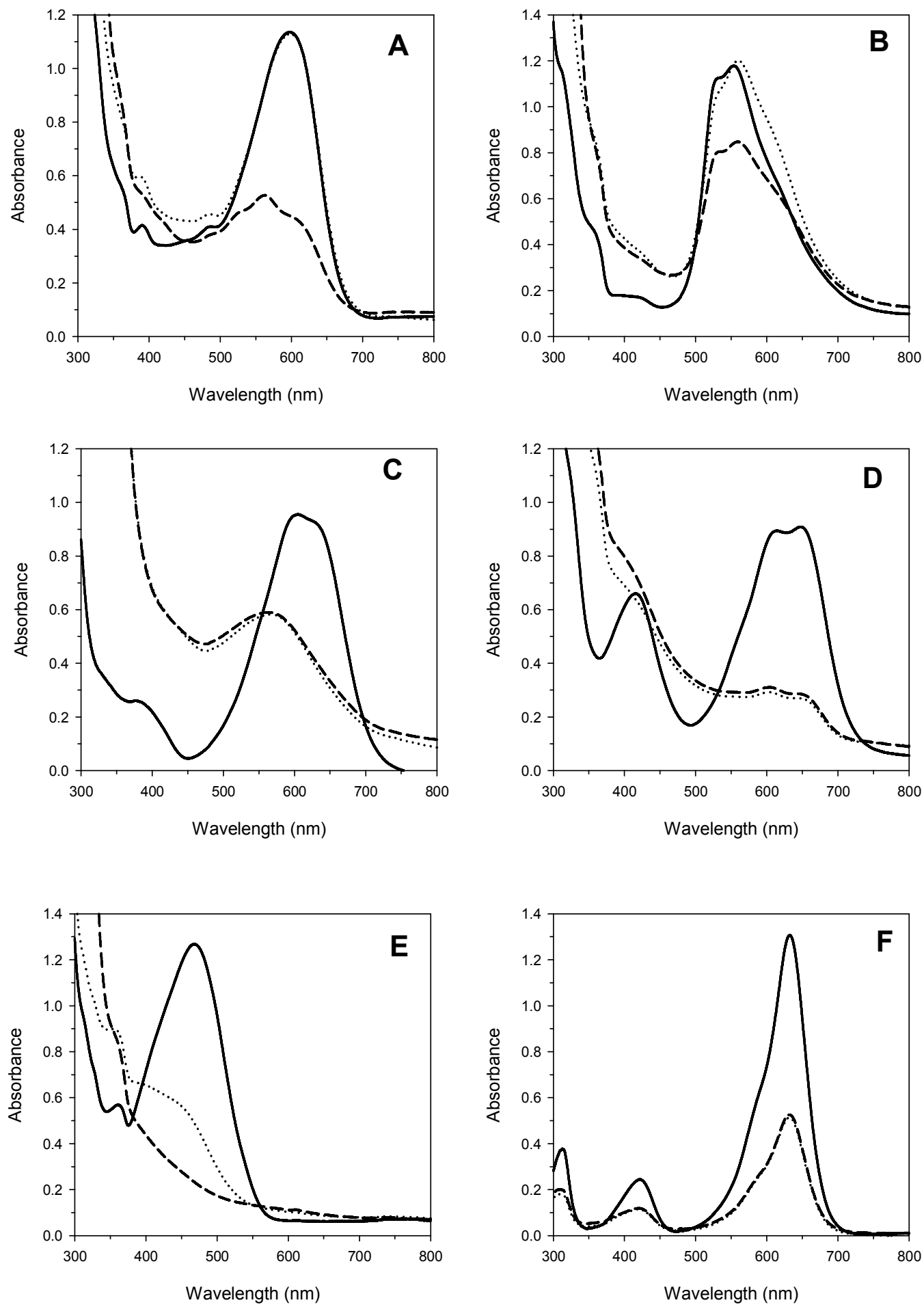

Fig. 7 

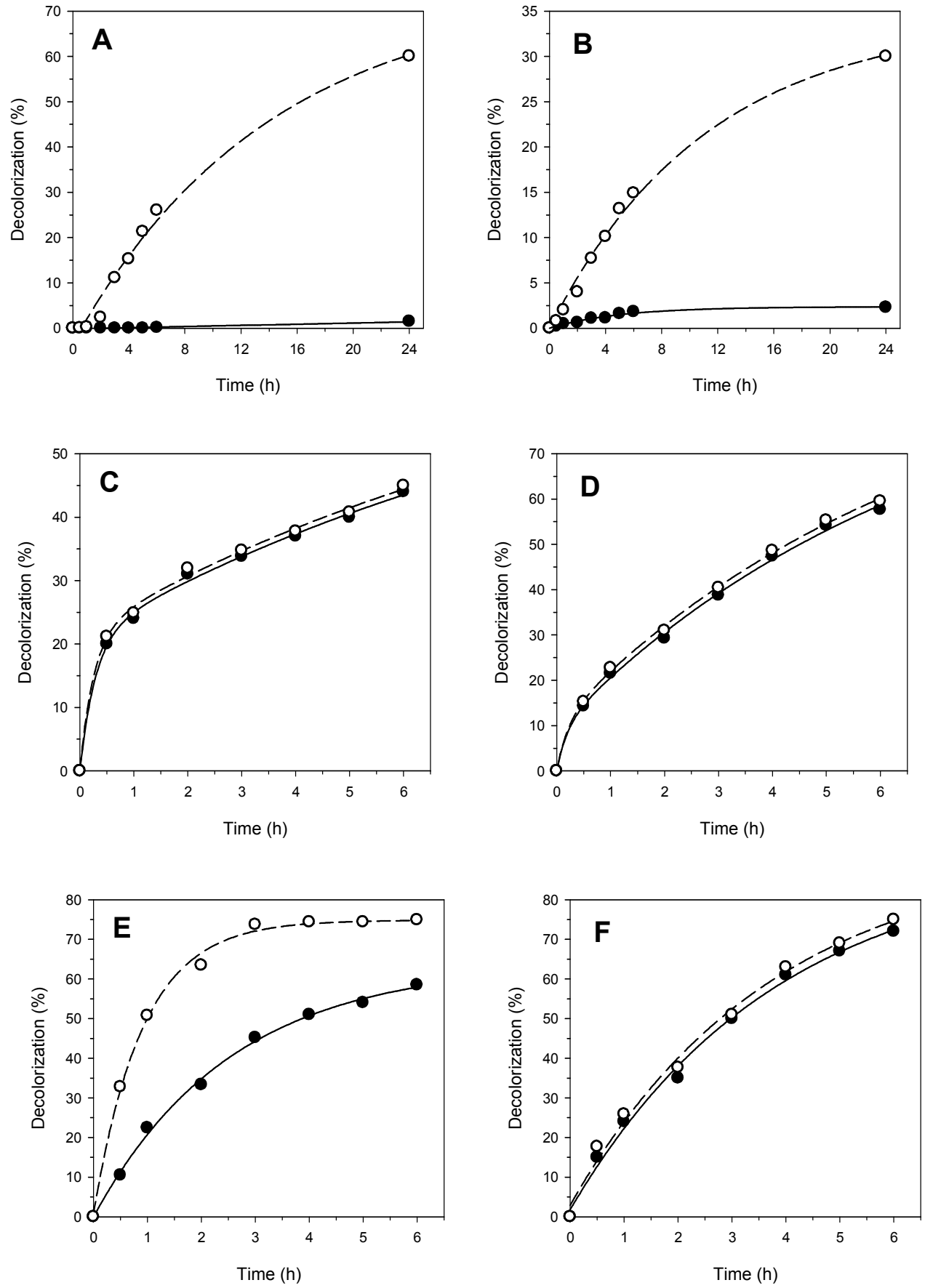

Fig. 8 


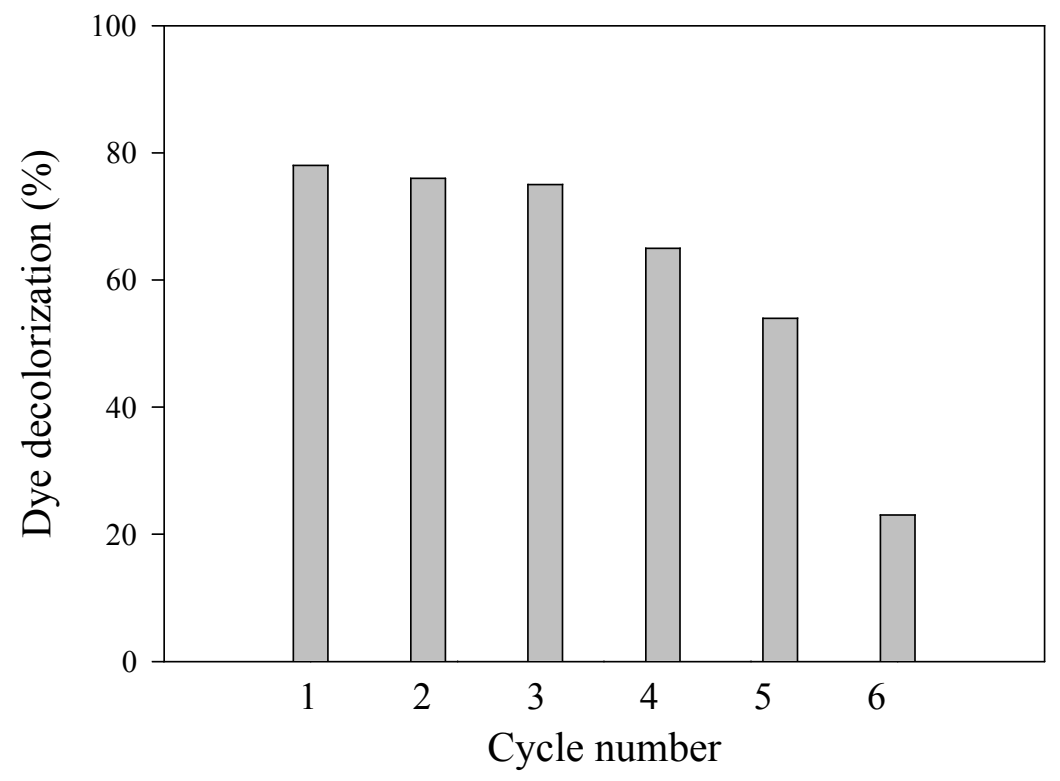

Fig. 9 